\title{
Gender, Agriculture, Food and Nutrition Security in Ethiopia: A Critical Review
}

\author{
Metadel Fekad* \\ Lecturer at Department of rural development and agricultural extension Mekelle University, Mekelle, Ethiopia
}

*Corresponding Author: Metadel Fekad, Lecturer at Department of rural development and agricultural extension Mekelle University, Mekelle, Ethiopia

\begin{abstract}
Agriculture is the backbone of Ethiopia's economy and sources of export earnings. Food security, food systems, and climate change are each multifaceted topics. Their interactions are likewise complex and are affected by a wide range of environmental and socioeconomic factors. Women play a vital role in food production, food distribution, and food utilization the three components of food security; they also undertake a range of community-level activities that support agricultural development, such as soil and water conservation, afforestation and crop domestication. Women face numerous obstacles to access productive inputs, assets and services; these obstacles not only heighten their vulnerability to food insecurity, but also considerably reduce their contribution to overall agricultural production. The objective of the review is to understand the gender-differentiated roles in agriculture and food and nutrition security in Ethiopia. Identify appropriate responses to close the gender gap in the agricultural sector in order to achieve gender equality and food security. Nutrition-specific policies directly targeting the nutritional status of women and the poor should be developed. Nutrition-sensitive policies, which target broad underlying factors including agriculture and food access, sanitation and women's empowerment. To better support food and nutritional security, policies are required to reform production mechanization and land tenure for the benefit of small-scale farmers, to reform how smallholders obtain agricultural inputs and to recognize agriculture as vehicle for investment option. Research should support women in tree domestication to improve the yields of tree foods, and seek to enhance the complementarity and stability of food production in smallholders'.
\end{abstract}

Keywords: gender, food and nutrition security, agriculture

\section{INTRODUCTION}

In Africa, agriculture is the mainstay of 70 percent of the continent's population and this critical sector will be most impacted by climate change. Agriculture is the backbone of Ethiopia's economy and sources of export earnings and employs many citizens. Its performance has a great impact on businesses, food systems, trade and livelihood of the population. Agricultural and trade policies, together with infrastructure and natural resource management heavily influence the food production, processing, distribution and marketing mechanism and subsequently the availability of food. Smallholder rain-fed agriculture, which is the mainstay of rural communities in Ethiopia, is negatively affected by climate change. Rainfall is highly erratic and there is a high degree of variability in both time and space (NMA 2007; EPCC 2015). Since agriculture (which employs around 85\% of the labor force, contributes more than $50 \%$ of the GDP and supplies $90 \%$ of export values) is climate sensitive, it is likely to remain the main engine of growth in the country, and climate-induced shocks will continue to be a threat to macroeconomic stability and could cause a remarkable loss in the total production unless strong remedial actions are put into action (MoFED 2010; EPCC 2015).

Food security, food systems, and climate change are each multifaceted topics. Their interactions are likewise complex and are affected by a wide range of environmental and socioeconomic factors. It is nevertheless clear that there are multiple connections between changing climate conditions and food systems and that climate change affects food systems in ways that alter food-security outcomes.

Women play a vital role in food production, food distribution, and food utilization the three components of food security; they also undertake a range of community-level activities that support agricultural development, such as soil and water conservation, afforestation and crop domestication. Women face numerous obstacles to access productive inputs, assets and services; these obstacles not 
only heighten their vulnerability to food insecurity, but also considerably reduce their contribution to overall agricultural production. Agriculture is central to women's livelihoods, especially in Ethiopia. Climatic stresses on agricultural production will make women particularly vulnerable to food insecurity. Women often face a greater burden in responding and adapting to climatic stresses due to their lack of access to land, financial services, social capital and technology. In some cases, discriminatory social attitudes and traditions are sanctioned by law. Empowering women and girls is not just necessary for their well-being, but also a means to broader agricultural development and food security, and it is economically sound. Different Studies shows that, if women farmers were given the same access to resources (such as land, finance and technology) as men, their agricultural yields could increase by 20 to 30 percent; national agricultural output could rise by 2.5 to 4 percent; and the number of malnourished people could be reduced by 12 to 17 percent. Eliminating gender-based discrimination under the law, ensuring gender-sensitive policies and programming decisions, and giving women greater voice in decision-making at all levels are necessary for mainstreaming gender in agriculture and food security.

\section{PURPose OF THE PAPER}

This paper provides basic information and insights to understand and advocate for integration of gender issues in agriculture and food security. The following themes are covered:

- The different roles of men and women in agriculture and food and nutrition security in Ethiopia

- Gender dimensions of climate stressors on agricultural production and food and nutritional security

- The need and options for integrating gender perspectives into agricultural and food security policies

\section{Specific Objectives of the Review Paper}

- Understand the gender-differentiated roles in agriculture and food security in Ethiopia.

- Understand the gender-differentiated impacts of climate change on agriculture and food security in Ethiopia.

- Identify the gender gaps in the agricultural sector that make women particularly vulnerable to food insecurity as well as show they hinder agricultural development in rural communities.

- Identify appropriate responses to close the gender gap in the agricultural sector in order to achieve gender equality and food security.

\section{Methodology}

The review was designed to provide information on areas of the gender, agriculture food and Nutrition security related papers were reviewed. The study used various tools to collect the data from Google scholar to reviewing of plother countries experience in gender, agriculture and food security.

\section{RESUlT AND DISCUSSION}

The review takes Indian experience as case study

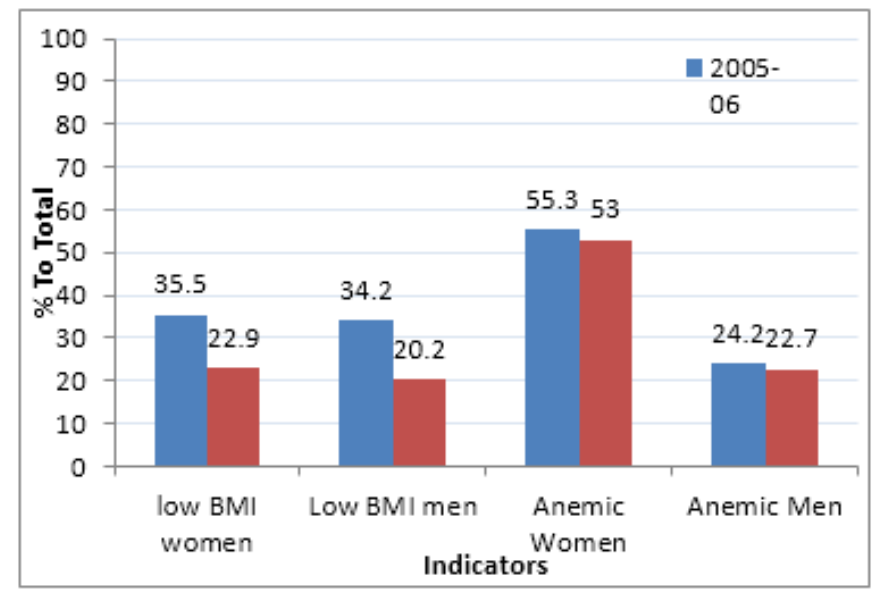

- $\%$ of women with low BMI reduced by 12 points,

- $\%$ of men with low BMI reduced by 14 points 
- A higher gender gap of 2.7 points in 2015-16

- Anaemia decline was higher for women and gender gap in 2015 reduced from 2005-06.

Direct intervention for women and child nutrition

Behavioral change interventions

- Breastfeeding and Complementary feeding promotion

- Hand washing with soap and promotion of hygienic behaviour

Micronutrient and de-worming interventions

- Vitamin A, Therapeutic zinc and Iodine supplementation

- Multiple micronutrient powders

- De-worming

- Iron-folic acid supplements for pregnant women

- Iron fortification of staples

- Salt iodization

Complementary feeding interventions

- Prevention or treatment of moderate malnutrition

- Treatment of severe acute malnutrition (Sonne, 2017)

As studies revealed agriculture programmes can ensure production of nutritional food by:

- Including nutritional goals and quality of produce in agriculture programmes,

- Bio-fortification (breeding crops especially rich in micronutrients),

- Providing incentives for farmers to grow crops with high nutritional value.

- Emphasize the importance of clean hygienic environments and practices for children

- Tailor nutritional support to those that are ill

\section{Agriculture For FoOd Production}

Solving the problems of food and nutritional security requires among other interventions a range of interconnected agricultural approaches, including improvements in staple crop productivity, the bio fortification of staples, and the cultivation of a wider range of edible plants that provide fruits, nuts, vegetables, etc., for more diverse diets (Frison et al. 2011). Potential for the diversification of crop production lies in the great range of lesser-used indigenous foods found in forests and wooded lands that are often richer in micronutrients, fibre and protein than staple crops (Leakey 1999, Malézieux 2013). Although such foods have traditionally been harvested from forests and woodlands, access to these resources is declining with deforestation and forest degradation (FAO 2010). In this context, cultivation provides an alternative resource. Moreover, the yield and quality of production can be improved during cultivation if attention is given to genetic improvement and the adoption of efficient farm management methods, making planting an attractive option: for many wild trees, including indigenous fruits, a two-fold yield improvement or more is possible through genetic selection (Jamnadass et al. 2011).

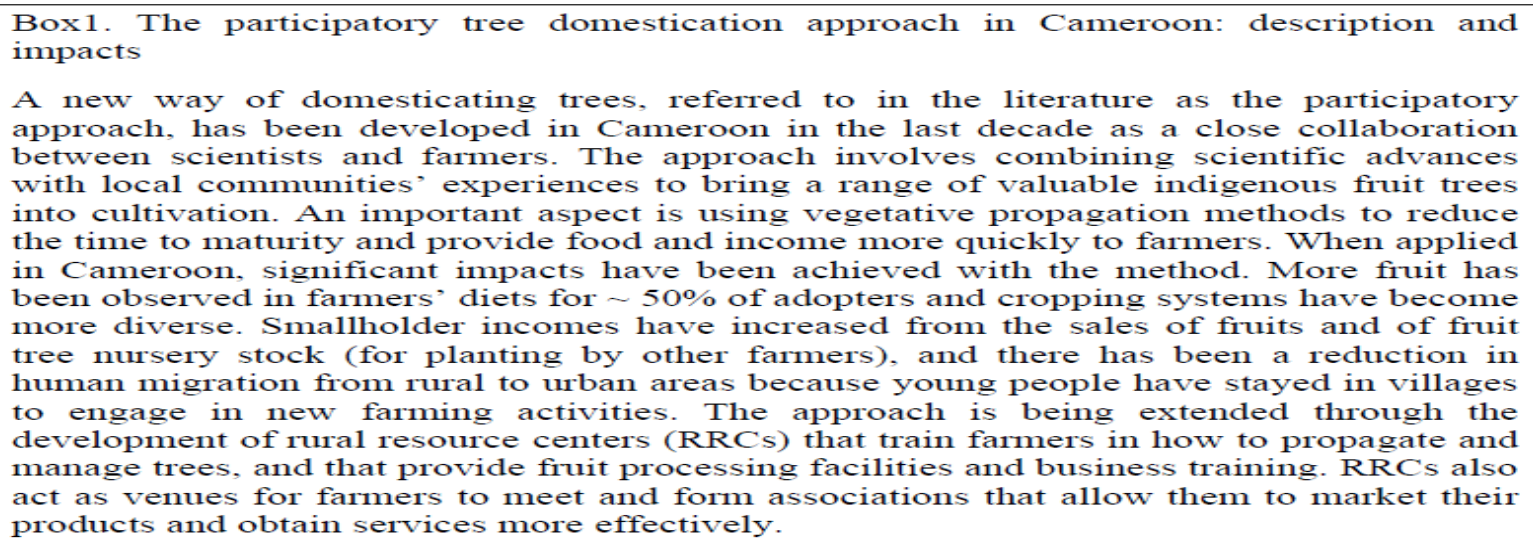




\section{Conflict Management Strategies in Natural ResourCeS}

These are the basic and fundamental conflict management strategies.

- Collaboration (win/win)- concerns are specific-time and energy

- Compromise (winsome /lose some)- temporary solutions

- Competition (win/lose)-bargaining

- Accommodation (lose/win)- important to others (specific purpose)

- Avoidance (lose/lose)-This strategy is generally used when the issue is trivial or other issues are more pressing.

\section{Options to INCREASE THE ROLE OF AgRiculture AND Forest In SUPPORTING FoOd AND NUTRITIONAL SECURITY}

\subsection{Policy Opportunities}

Guidelines were revised recently for policymakers to support agroforestry development (FAO 2013b). They recommend, for example, reforming unfavorable regulations, legal restrictions and restrictive financial mechanisms that inhibit the practice of agroforestry; clarifying land-use policy goals and regulations; elaborating new policies that acknowledge the role of trees on farms in development; and strengthening farmers' access to markets for tree products. Several countries, including Brazil, are developing or refreshing their agroforestry strategies in a participatory way with local communities, while the governments of China and India have embarked on ambitious programmes to increase tree cover outside forests. More attention should be given to food trees in such programmes. Some governments are setting minimum requirements for tree cover on farms. In Kenya, where a minimum of $10 \%$ cover has been set, the government has allocated funds to assist farmers to meet this requirement. Agroforestry is recognized under the United Nations Framework Convention on Climate Change as a key mitigation method within agriculture, and national climate change adaptation plans need to further embrace agroforestry as a climate-smart agricultural response.

\subsection{A Three-Step Approach for Agroforestry to Support Food and Nutritional Security}

Leakey (2010) described a step-wise multifunctional agricultural approach by which agroforestry can further support food and nutritional security: (1) support for soil fertility replenishment technologies is followed by (2) participatory tree domestication (box 4) and then (3) by entrepreneurship and valueaddition to tree products. Potential interventions to benefit local communities in enterprise development include value chain analysis as undertaken, for example, by Techno Serve to improve banana markets in East Africa, where multiple brokerage levels deprived farmers of significant revenues (Milder 2008). Based on the Techno Serve analysis, smallholders were organised into producer business groups linked directly to wholesale banana buyers, which resulted in an increase in farmer income of over $80 \%$. In the context of food and nutritional security, 'nutrient-sensitive' value chains are required. This means improving nutritional knowledge and awareness among value-chain actors and consumers, focusing on promoting the involvement of women, and considering markets for a wider range of tree foods. By promoting tree food processing and other value additions, the nonfarm rural economy can also be stimulated.

\subsection{Planning for Climate Change}

One way in which food production through agroforestry practices can be adapted to climate change is by adjusting the tree composition of systems to take account of new environmental conditions (Dawson et al. 2011). Changes in composition can be made at the interspecific and intraspecific levels, the latter making use of within-species variations in growth and phenology in differing conditions. At the species level, the selection of 'generalist' food trees that grow well under varied conditions may be an important response, although this could result in a few highly adaptable exotics becoming dominant, which would be undesirable in providing a wide range of products and tree services. Another approach to planning for the future is to develop vegetation maps and explore how these will change under different climate scenarios. The best sites for planting particular tree species can be planned accordingly. 
Box 3. Integrating markets and cultivation to support the sustainable development of a new tree commodity crop: the case of allanblackia

The seed of allanblackia (Allanblackia spp.), found wild in the humid forests of Central, East and West Africa, yield edible oil with a significant potential in the global food market, especially as a 'hardstock' for the production of healthy spreads that are low in trans-fats. A private-public partnership known as Novella Africa is developing a sustainable allanblackia oil business that could be worth hundreds of millions of USD annually for local farmers. A supply chain for seed has been established in Ghana, Nigeria and the United Republic of Tanzania, based on harvesting by local communities in natural forests and from trees remaining in farmland after forest clearance. Currently, volumes are small (hundreds of tonnes) and oil is exported for food product development. At the same time, the tree is being brought into cultivation by improving seed handling and developing vegetative propagation methods, and through the selection of superior genotypes. Tens of thousands of seedlings and clones have so far been distributed to smallholders. The integration of allanblackia into smallscale cocoa farms is being promoted in West Africa to support more biodiverse and resilient agricultural landscapes. As allanblackia trees grow, cocoa trees provide the shade they need; when they are grown, they in turn will act as shade for cocoa. Cocoa and allanblackia provide harvests at different times of the year and when the allanblackia trees have matured - will spread farmers' incomes.

Source: adapted from Jamnadass et al. (2010)

\subsection{Gender Roles in Agriculture}

Here the paper tries to review and understand the linkages among gender, agriculture and food and nutrition security. Gender is a social construct specifying the socially and culturally prescribed roles that men and women are to follow.

Agriculture and food security are characterized by gendered dimensions in that women play a key role in agricultural production, food processing and marketing. They play a decisive role in dietary diversity and are responsible for nutrition in the home. In addition, women are involved in the production and domestication of plants and animals; they are knowledgeable in seed selection and vegetative propagation; they understand how plants and animals grow and reproduce; and they plant trees. Women comprise 20 to 50 percent of the agricultural labour force in developing countries (FAO 2011b) and 79 percent of women in least developed countries who are economically active report that agriculture is their primary economic activity (Doss 2011). While the roles of women in agriculture vary widely by region, age, ethnicity and social station, their participation rates in the agricultural labour force in sub-Saharan Africa is the highest in the world. For example, the percentage of women in agricultural activities ranges from 36 percent in Côte d'Ivoire and Niger to over 60 percent in Lesotho, Mozambique and Sierra Leone (FAO 2011b).

\section{THEORIES OF GENDER DEVELOPMENT}

\section{- Social Learning Theory}

Proponents of this theory believe that parents, as distributors of reinforcement, reinforce appropriate gender role behavior.

\section{- Cognitive-Developmental Theory}

This is derived from Kohlberg's speculations about gender development. Children begin the process of acquiring gender-appropriate behavior.

\section{- Gender Schema Theory}

It helps a child to develop gender identity \& formulate an appropriate gender role.

\section{- Schema}

it is a mental blueprint for organizing information, and children develop and formulate an appropriate gender.

\section{- Gender Ideologies}

attitude toward men \& women role. 


\section{- Traditional Gender Ideology}

Maintains that men sphere is work and women sphere is the home.The implicit assumption is that men have greater power than women.

\section{- Egalitarian Gender Ideology}

Maintains that power is distributed equally between men and women and that each group identifies equally with the same spheres.

\section{- Transitional}

It is acceptable for women to devote energy to both work and family domains but women should proportionally more responsibility for the home and men should focus proportionally more their energy on work.

\section{CONCLUSION AND RECOMMENDATION}

Agriculture is the backbone of Ethiopia's economy and sources of export earnings and employs many citizens. But there is gender gap and resource ownership difference among women and men farmers. Majority farmers operate on small scale and often find difficult to adjust to uncertainties, especially the risks from extreme weather events. It is better to introduce Crop insurance for women farmers like comprehensive crop insurance scheme (CCIS) includes (covering cereals, millets, pulses and oilseeds) to National Agricultural Insurance Scheme (NAIS) - MNAIS - Weather Based Crop Insurance Scheme (WBCIS) as if it is productive and advantageous in India. Since WBCIS is aimed to mitigate the hardship of insured farmers against the likelihood of financial loss from adverse climatic conditions. WBCIS uses weather parameters (Rainfall, temperature, humidity, winds) as 'proxy' for crop yields in compensating the cultivators for deemed crop losses.

\section{Recommendation}

The development of agro forestry policy should not be confined to the agricultural or forest sectors; it needs a place of its own. Required reforms include targeting tree and land tenure, how farmers obtain the trees they plant, and the recognition of agro forestry as an investment option for food production.

Nutrition-specific policies directly targeting the nutritional status of women and the poor should be developed. Nutrition-sensitive policies, which target broad underlying factors including agriculture and food access, sanitation and women's empowerment. e.g.

- higher Minimum Support Prices for crops

- loans for construction of toilets

- assistance to women farmers

- Water, sanitation, hygiene and health

Creating conducive environments for women to reduce their food security problem by involving them in agro forestry to supports food and nutritional security through: (1) the direct provision of tree foods such as fruits and leafy vegetables and by supporting staple crop production; (2) by raising farmers' incomes through the sale of tree products and surplus staples; (3) by providing fuels for cooking; and (4) by supporting various ecosystem services such as pollination that are essential for the production of some food plants.

To better support food and nutritional security, developments in agro forestry policies are required to reform production mechanization and land tenure for the benefit of small-scale farmers, to reform how smallholders obtain agro forestry inputs such as tree seed and seedlings, and to recognize agro forestry as an important investment option. Research should support women in tree domestication to improve the yields of tree foods, and seek to enhance the complementarity and stability of food production in smallholders'.

Involve rural communities, especially women, in the planning and carrying out of climate change adaptation initiatives in development and adaptation plans and policies. Develop awareness and information campaigns about climate change and its effects for inhabitants of rural areas. Promote awareness raising and training among those involved in rural development (at national, regional and 
local levels) with regard to the specific impact that climate change has on women. Involve rural communities and women in particular, in the sustainable management of resources such as water and forests. Promote adapted farming systems, the use of water- and soil-conservation techniques, reforestation and sustainable resource management. Improve women's access to land ownership; develop awareness raising programmes within communities and among those involved in development at local, regional and national levels. Promote the amendment of laws to grant women the right to ownership.

Promote women's access to agricultural-extension services and training on farming adaptation techniques. Improve women's access to credit and the inputs needed to increase agricultural yield. Promote access for both men and women farmers to information about the climate, including weather forecasts, so that they can decide on the best time to plant seeds. Promote suitable frameworks and tools for analyzing interactions between climate change and development, with a view to consistently incorporating climate change into planning at national, regional and local levels. Explicitly promote the integration of women throughout agriculture and nutrition project cycles and promote outcomes that increase food security, especially for women and girls. Integrate the needs of women and girls into agriculture investments and promote outcomes that equally benefit men and women, boys and girls.

\section{REFERENCES}

[1] Dawson I K, Vinceti B, Weber J C, Neufeldt H, Russell J, Lengkeek A G et al. 2011. Climate change and tree genetic resource management: maintaining and enhancing the productivity and value of smallholder tropical agroforestry landscapes. A review. Agroforestry Systems 81:67-78.

[2] United Nations Food and Agriculture organization (FAO). 2010. Global forest resources assessment 2010. FAO Forestry Paper No. 163. Rome: Food and Agriculture Organization of the United Nations.

[3] FAO (2011b). The State of Food and Agriculture, Rome: FAO.

[4] FAO. 2013b. Advancing agroforestry on the policy agenda: a guide for decision-makers. Agroforestry Working Paper No.1. Rome: Food and Agriculture Organization of the United Nations.

[5] Frison E A, Cherfas J, Hodgkin T. 2011. Agricultural biodiversity is essential for a sustainable improvement in food and nutrition security. Sustainability 3:238-253.!!

[6] Jamnadass R H, Dawson I K, Franzel S, Leakey R R B, Mithöfer D, Akinnifesi F K et al. 2011.

[7] Improving livelihoods and nutrition in sub-Saharan Africa through the promotion of indigenous and exotic fruit production in smallholders' agroforestry systems: a review. International Forest Review 13:338-354.

[8] Jamnadass R, Place F, Torquebiau E, Malézieux E, Iiyama M, Sileshi GW, Kehlenbeck K, Masters E, McMullin S, Weber JC, Dawson IK. 2013. Agroforestry, food and nutritional security. ICRAF Working Paper No. 170. Nairobi, World Agroforestry Centre. DOI: http://dx.doi.org/10.5716/WP13054.PDF

[9] Leakey R R B. 1999. Potential for novel food products from agroforestry trees. Food Chemistry 64:1-14.

[10] Leakey R R B. 2010. Agroforestry: a delivery mechanism for multi-functional agriculture. In: L R

[11] FDRE, 2012. Ethiopia's progress towards eradicating poverty: An interim report on poverty analysis study (2010/11). Addis Ababa, Ethiopia.

[12] Kidane W, Maetz M \& Dardel P, 2006. Food security and agricultural development in Sub-Saharan Africa (SSA): Building a case for more public support. Rome: FAO.

[13] EPCC. (2015). First Assessment Report, Working Group II Agriculture and Food Security. Addis Ababa: Ethiopian Panel on Climate Change (EPCC), Ethiopian Academy of Sciences.

[14] MoFED. (2010). Growth and transformation plan (2010/11-2014/15); Volume I: Main text. Addis Ababa: Ministry of Finance and Economic Development (MoFED).

[15] Kellimore, ed. Handbook on agroforestry: management practices and environmental impact. Environmental Science, Engineering and Technology Series. Hauppauge: Nova Science Publishers, p.461-471.

[16] Milder B. 2008. Closing the gap: reaching the missing middle and rural poor through value chain finance. Enterprise Development and Microfinance 19:301-316.

[17] Malézieux E. 2013. Editorial. Underutilized fruit trees in Africa. Special Issue. Revue Fruits (in press).

[18] Tchoundjeu Z, Degrande A, Leakey R R B, Nimino G, Kemajou E, Asaah E. et al. 2010. Impacts of participatory tree domestication on farmer livelihoods in West and Central Africa. Forests, Trees and Livelihoods 19:217-234.

[19] United Nations Development Programme (2010). Gender, Climate Change and Community-Based Adaptation, New York.

[20] United Nations Development Programme (2007, 2011). Human Development Report, New York. 
[21] World Health Organization (2011). Gender, Climate Change and Health, Geneva: WHO.

[22] World Bank (2009). Gender in Agriculture Sourcebook, Washington, DC: World Bank.

[23] World Bank (2010). Social Dimensions of Climate Change, Washington, DC: World Bank.

[24] World Bank (2010; 2011b). World Development Report, Washington, DC: World Bank.

Citation: Metadel Fekad. "Gender, Agriculture, Food and Nutrition Security in Ethiopia: A Critical Review" International Journal of Research Studies in Agricultural Sciences (IJRSAS), 2020; 6(2), pp. 14-21, http://dx.doi.org/10.20431/2454-6224.0602003

Copyright: (C) 2020 Authors. This is an open-access article distributed under the terms of the Creative Commons Attribution License, which permits unrestricted use, distribution, and reproduction in any medium, provided the original author and source are credited. 